The University of San Francisco

USF Scholarship: a digital repository @ Gleeson Library | Geschke Center

2015

Playing the Whore: Illicit Union and the Biblical Typology of Promiscuity in the Toledot Yeshu Tradition

Natalie Latteri

Follow this and additional works at: https://repository.usfca.edu/thrs

Part of the Jewish Studies Commons 


\title{
Playing THe Whore: \\ Illicit Union and the Biblical Typology of Promiscuity IN THE Toledot Yeshu Tradition
}

\author{
Natalie E. Latteri
}

\begin{abstract}
Toledot Yeshu, or "Stories about Jesus," have been transmitted by Jews for centuries but only recently have begun to garner significant scholarly attention as part of a tradition of anti-Christian polemic. This paper contends that the varied depictions of Jesus' conception in the Toledot corpus reflect the intracommunal issues of forced conversion, apostasy, and overfamiliarity with non-Jews. The theme was neither new to the Toledot nor a product of the late-antique and medieval contexts that Jewish stories of Jesus first circulated in. Rather, it echoes biblical representations of, and admonishments against, illicit relationships with non-Jews which ancient authors commonly depicted through a typology of sexual promiscuity. It is only when viewing Toledot presentations of Jesus' conception in light of both contemporary events and the Jewish biblical literary tradition that we are able to grasp their previously unnoted functions as 1) Jewish selfcriticism regarding intercommunal relations; and, 2) a didactic warning to future generations against making similar mistakes.
\end{abstract}

Once there was a Jewish woman, Miriam, who lay with a man other than her husband and conceived a child, Yehoshua, Yeshu for short. A bastard and thus a blemish on his family's reputation from the start, young Yeshu would grow to become the bane of his community as well: not only was he a precocious student who disrespectfully challenged his teachers' authority, he led many Jews to stray from Judaism due to his ability to perform wondrous acts. Indeed, it was only because of his wit and craft that many believed his claims that he was the awaited Messiah and the Son of God. But the wise leaders of the community were able to secure his execution by showing Yeshu was only able to perform wonders through magic rather than miracle. After his death, a Jewish gardener guarded Yeshu's body in order to prove that he had not been resurrected, as his followers believed he would be. Still, they continued to agitate the community with their protests that Yeshu was the Messiah. It was only after a pious and learned Jew, Paul, convinced those who persisted in their unorthodox beliefs to separate themselves from the community that the dissenters established a different religious identity as Christians.

$$
\text { SHOFAR } 33.2 \text { (2015): 87-102 | } 87
$$


What I have related above is a coarse plot summary of Toledot Yeshu, or "Stories about Jesus," that have been transmitted by Jews for centuries in both oral and written form. ${ }^{1}$ As may be expected, there are many different versions of Toledot extant in Hebrew, Aramaic, and Yiddish. These contain shared details as well as text-specific ones, and numerous rhetorical resonances that my synopsis does not. ${ }^{2}$ For instance, in some versions, Yeshu is portrayed as picking up his wonder-working abilities during a stay in Egypt. ${ }^{3}$ One story that shares this detail relates that, due to the cool reception of his illegitimacy, Yeshu fled his native Nazareth and resided in the foreign land of Egypt where he learned the inhabitants' religious practices. ${ }^{4}$ In other versions, though, Yeshu is depicted as stealing the Ineffable Name from the Temple in Jerusalem by writing it on parchment and hiding it in a laceration designed for that purpose on his thigh. ${ }^{5}$ In the former scenario, the source of Jesus' power is Egyptian—shorthand for quintessentially mysterious and magical in Judeo-Hellenistic and subsequent Judeo-Christian idiom—and thus tainted with idolatry by association with supernatural powers other than the Jewish God. ${ }^{6}$ In the latter scenario, the source of Yeshu's power is known and holy, derived directly from the cultic trappings of Second Temple Judaism and advanced theological knowledge. However, the means by which it was secured amounted to impious blasphemy.

The details of the various versions differ, but the message is fundamentally the same: Yeshu's ability to work wonders was not bestowed on him from God, either as from a father to a son or to His chosen Messiah; rather, it was secured by scurrilous means and aptly resulted in an ignominious death. The simplest didactic point being made was that the retribution for blasphemy (or idolatry, depending on the version) amounted to public shaming and execution. Incidentally, the same point was iterated in the biblical text time and again. The book of Leviticus, for instance, relates that when a young man-the offspring of an Israelite woman and an Egyptian manblasphemed, God commanded Moses to have him removed from the camp and stoned to death by the community as a precedent of how to punish subsequent offenders (Lev 24:10-16). And, in the book of Numbers, God commands faithful Israelites to make a public spectacle of their former coreligionists who had committed idolatry after being lured by foreigners and, in due course, their gods, by impaling them "in the sun before the Lord" as a sacrifice of atonement and, presumably, as a warning to others (Num 25:4). ${ }^{7}$

Regardless of the traditional biblical bent, the didactic message of Toledot has been overlooked or underemphasized in recent studies. Instead, scholars have tended towards philological analyses, and with admirable at- 
tention to detail many have concentrated on what distinguishes one text (or one group of texts) from others. In the process, they have shown that variations in idiom and content are largely dependent on context-that is, the received traditions in a certain time and place and the function stories about Jesus might have fulfilled for the communities that continued to transmit them. ${ }^{8}$ Differences withstanding, because the majority of extant recensions suggest Jewish composers or copyists writing for a Jewish audience and due to the largely unfavorable representation of Jesus in Toledot, the tradition is primarily categorized as an anti-Jesus, and thus anti-Christian, polemic..$^{9}$ I do not deny this function; however, this paper reiterates that Toledot were stories written and told by Jews for Jews. Their purpose extends beyond providing a defamatory counternarrative of the origins of Christianity to addressing intracommunal issues.

In particular, the varied depictions of Jesus' conception reflect the reality of forced conversion, apostasy, and overfamiliarity with non-Jews in medieval Ashkenaz. The theme was neither new to the Toledot nor a product of the late-antique and medieval contexts that Jewish stories of Jesus first circulated in. Rather, it echoes biblical representations of, and admonishments against, illicit relationships with non-Jews which ancient authors commonly depicted through a typology of sexual promiscuity. It is only when viewing Toledot presentations of Jesus' conception in light of both contemporary events and the Jewish biblical literary tradition that we are able to grasp their previously unnoted functions as 1) Jewish self-criticism regarding intercommunal relations; and, 2) a didactic warning to future generations against making similar mistakes.

I began this paper with a pared-down version of Jesus' conception according to a Jewish rendering of events in which a Jewish woman lay with a man other than her husband and conceived a child. My retelling is not far from a common version of Jesus' conception in Toledot circulating in northwestern Europe during the late Middle Ages through the early modern era, known to posterity as the Helen/a, or alternately, the Wagenseil version. ${ }^{10}$ In it, Miriam is described as conceiving Jesus as a product of intercourse with a "wicked" Jewish man named Joseph ben Pandera. It relates that, though Miriam was betrothed to Yochanan of the house of David, Joseph ben Pandera of the tribe of Judah paid no mind. He successfully stole into her house in the night and, because it was dark, was able to pretend to be her betrothed and engage in sexual relations with her, albeit against her will. When Yochanan discovered what had happened, he fled to Babylon so that he would not be the cuckolded laughing stock of the community. 
The details of Jesus' conception differ depending on the version. In some, Miriam was tricked by an unnamed impious Jew and when her rightful husband, Joseph, discovered what had happened, he fled Nazareth with Miriam. They went to Egypt to raise Yeshu alongside his younger siblings (Miriam's children who were products of subsequent illicit unions) as if they were Joseph's. ${ }^{11}$ In other versions, Miriam was married to a man named Pappos who locked her inside the house while he was away so that other men might not engage in sex acts with her. Despite Pappos' efforts, Miriam willingly agreed to flee with a Gentile soldier, Joseph Pandera, and become his mistress, giving birth to Yeshu as a result of their dalliance. ${ }^{12}$

Contradictory details are not without their significance. The alternate presentations of trickery and rape versus the complicity of Miriam, as well as the assignment of alternate names for her betrothed/husband and her rapist or lover, each potentially contain a range of anti-Christian polemics. And understanding the role that specific details could have played provides an indication of what popular ideas Jewish authors and transmitters of Toledot may have been responding to within their own era and geographical region. ${ }^{13}$

Along these lines, some scholars have argued that the idea of the conception of Yeshu as a product of rape is one that originated when Mariolatry was at its height in continental Europe. They interpret the scenario as a sympathetic presentation that attempted to expunge Mary of any guilt since, within the narrative, judges of the Bet Din do not punish her for adulterous relations because she was either a misinformed or unwilling party. The elements of the subterfuge and rape, as well as the later decision of the court, were contrived as either a safeguard against enraging Christians who were devoted to Jesus' mother or were owing to a development of positive attitudes among medieval Jews towards Mary as a benevolent intercessor. ${ }^{14}$

This reading is problematic because it suggests that 1) Toledot authors either wrote for a Christian audience or, at the very least, that they were concerned about the fact that Christians may read or hear Toledot; and 2) that the consistent presentation of Yeshu/Jesus as a false Messiah was not sufficient to enrage Christians should they come across it, defamation of Mary was also necessary. The former implication is based on a false premise: the languages Toledot were typically composed in (Aramaic, Hebrew, and Yiddish) belie a Jewish audience. ${ }^{15}$ Moreover, that late medieval Toledot does contain an extended reference to Jesus' conception as a product of rape is probably due to an embellishment of an earlier version in circulation among the Jews of Carolingian France and not owing to ideas presumed to have developed later and of a more benevolent nature. 
Although a recension is not extant, the ninth-century archbishop of Lyons, Amulo, complained of a pernicious story told by contemporary Jews in a letter to Charlemagne (Contra judaeos) in which he inveighed against Jewish sociopolitical and economic prominence in the realm. According to his account, Jews were so confident of their position in Charles's territory that they openly blasphemed the Holy Family, spreading rumors that Mary had been "defiled" (adulteram) by an "impious man, that is, of which heathen I know not, whom they [Jews] call Pandera," and thus conceived Jesus. ${ }^{16}$ Yet, even though rumored defilement of a passive Mary contributed to Amulo's aggravation, his limited treatment of the topic suggests it was not a fundamental component of his critique of Toledot. Likewise, his predecessor to the archbishopric of Lyons, Agobard, had similarly complained to Charlemagne of Jewish blasphemies without indicating information about a Jewish account of Jesus' conception, in particular, or reference to Mary. ${ }^{17}$ Whether Agobard was unaware of or had deigned references too insignificant to mention in his letter, his omission suggests these were not essential elements.

Carolingian anti-Jewish sentiment had already been inflamed by Toledot that had little to do with Mary. High and late medieval recensions that elaborated on her nonconsensual role in Jesus' conception were not received more favorably. Ruth Karras has shown that a version of Toledot containing this detail was known in Vienna around the time of the major pogrom of 1420 - the Wiener Geserah - and was translated into Latin by the ecclesiastic Thomas Ebendorfer with the aid of a recent convert from Judaism. Whatever the intent of the translators may have been, this version functioned to further incite anti-Jewish sentiment and legislation, including mass execution and expulsion. ${ }^{18}$ And so, presenting Mary as a victim of rape was not perceived as a lenient or benevolent depiction of her by medieval Christians. It is both surprising and disturbing that it has been viewed as such by modern scholars.

That anti-Marian polemic has only been gauged by presentation of Mary's complicity in sex acts reflects misunderstanding regarding the function of rape. Domination and terrorism are its defining features and any unauthentic presentation of it can hardly be construed as a positive statement about the victim without recognizing the actual sociopolitical purposes of rape and questioning why it is that the Jewish authors and tellers of Toledot might have wanted to dominate and terrorize the character of Miriam. Declaring that the matriarch of Christianity had been assaulted in this manner, her hymen ruptured against her will, was not an effort to provide an account of actual events but to figuratively attack the construct of Mary-Christians' Blessed Madonna and Queen of Heaven-with every 


\section{2 | NATALIE E. LATTERI}

retelling. The fabrication aimed at blemishing perceptions of Mary's purity and diminishing the status of those loyal to her who believed her to be inviolate and who also, in some fashion, emulated her.

To clarify: the notion of a violated Mary slandered the origin of Christianity and a foundational element of the newer religion in a manner distinct from Toledot versions relating a consensual extramarital coupling. It explicitly defied the New Testament presentation of Mary as distinct among women and especially sought out by God, a woman who freely chose to accept the role as Jesus' mother and who, according to Church doctrine, maintained her status as "ever-virgin" and vessel of God throughout her life. ${ }^{19}$ And it implicitly challenged the belief held by Christians that they, like Mary, had 1) been chosen by God to fulfill a New Covenant as a New Israel and 2) that they, like her, freely chose to accept their role. ${ }^{20}$

Yet, however severe, anti-Christian polemic was not the only or even the most important function of Jewish stories about Jesus' conception. Jews were writing for Jews and their stories resonated, on some level, with internal communal issues that were affected by Christians, to be sure, but may not have been exclusively concerned with Christian doctrine. To better estimate what internal communal issues Toledot may have addressed, we return to the sparsest Jewish version of how Jesus was conceived and consider the circumstances, first at face value: a Jewish woman conceived a child with a man other than her husband.

Modern apathy may not be too far off from the antique response found in the Hellenized world. It is unlikely that Miriam was the first Jewish woman to conceive a mamzer. Moreover, it seems to have been common knowledge-or, at least common gossip—that she had done just that. In both Talmudic writings and Patristic apologetics, Jews, Greek Pagans, and Latin Christians appear familiar with the rumor that Miriam, though married, had a lover on the side who had sired her son. ${ }^{21}$ Even the Gospel of Luke relates that Jesus himself was not shy about publically pointing out that Joseph was not his father. ${ }^{22}$ Ironically, there is nothing in the Jewish or Christian cannons regarding any legal repercussions Miriam faced as a result of her widely rumored extra-marital affair, leading to the assumption that any actual act of fornication was of nominal significance to Jews who were in a position to preside over such cases at the turn of the Common Era-or, at the very least, to first-century Jews who may have been interested in reporting on the life of Jesus' mother. ${ }^{23}$ Thus, the appeal for Jews to tell and retell her story was hardly dependent on spreading rumors of sex acts Miriam had willingly engaged in or had had forced upon her that 
were believed to be based in historical reality. But it may have been a motif of interest to Jews who faced similar questions about the status of "defiled" or adulterous women in their own communities.

After all, the Toledot's sometime presentation of lenient judgment of Miriam and a denial of her culpability in the conception of Yeshu was a scenario that would have been familiar to a medieval Ashkenazic audience. Indeed, French and Germanic responsa literature of the high through late Middle Ages treats questions regarding the status of women who had been forcibly converted and presumably coerced into sexual couplings with men other than their rightful husband or fiancé; and the status Jewish women whose husbands had converted but who refused to divorce their wives, instead leaving them in the precarious position of marital limbo-neither wed to an active member of the community nor free to remarry without a bill of divorce from their erstwhile partner. ${ }^{24}$ It is not such a stretch, therefore, to see in Toledot accounts of a Jewish woman who was defiled by an impious heathen (i.e., a non-Jew, or, perhaps, a nonobservant or apostate Jew), or who was left in the lurch by a husband who chose to abandon her because of her defiled status, echoes of contemporary events affecting medieval Ashkenaz.

That Toledot end with a depiction of the division of the Jewish community into adherents of rabbinic Judaism on the one hand and proselytes to Christianity on the other hand serves, in this regard, not only as a recording of what may have transpired but also as a caution against similar leniency and the further division of the community it could produce. It intimates that, had Miriam's husband called attention to her defilement right away or had the Bet Din punished Miriam as it could have, ${ }^{25}$ Yeshu, if born at all, would have been raised under different circumstances and potentially would not have attempted to lead Jews astray or fracture the kehilah. And so, whether complicit in illicit sex acts or not, Toledot relate that Miriam's sex life ushered in a series of communal devastations and ultimately resulted in an altered communal identity.

High medieval Ashkenazic historical prose and liturgical poetry similarly include admonishments against leniency and hint at the threat of consensual or coerced illicit unions in connection with forced conversion and apostasy. ${ }^{26}$ For example, in the twelfth-century literary rendering of the persecutions and martyrdom of Ashkenazim associated with the beginning of the First Crusade, the author of the Chronicle of Solomon bar Samson related with gory detail how a Cologne parnas, Master Judah, slaughtered his son's bride, Sarit, as an act of kiddush ha-Shem. The words Solomon attributed to Judah as having spoken just before Sarit's murder convey a stringently 


\section{4 | NATALIE E. LATTERI}

antimiscegenationist position and his actions provide a model of most severe punishment for even potential illicit sexual coupling. The story follows that, when Judah sensed Sarit's fear of participating in the sacrificial scene the community was in the process of enacting and her desire to escape it (presumably through apostasy) he seized her and placed her in the arms of his son. After addressing her, saying "My daughter, since you did not have the privilege of wedding my son Abraham, you will not marry any Gentile either," Judah cleaved her in two before slaughtering his son as well. ${ }^{27}$

As an episode in a lengthy martyrology which provides justifications for halakhically questionable acts of suicide and homicide as a more pious option than either voluntary conversion accepted under duress or even physically forced conversions, this scene aligns potential illicit sexual couplings (a hypothetical marriage to a Gentile) with a diminished Jewish identity (via conversion as a precursor to the above hypothetical wedding and bedding), juxtaposed to the zeal of Jews who defined themselves through their willingness to perform kiddush ha-Shem. The contrast conflates the defilement of the body and soul and promotes the alternative-a sacrifice unblemished in the flesh or spirit-that is made explicit through rhetoric lauding the martyrs as a group who had died in purity for God.

Ashkenazic reality did not always conform to the staunch ideological position reflected in the Chronicle of Solomon bar Samson, but the treatment towards women who found themselves in positions similar to Sarit is closely related. In general, medieval rabbis vacillated between leniency and stringency regarding their treatment of various types of socioeconomic, halakhically questionable, relations with non-Jews. For example, some condoned selling Christians wine that could potentially be used in the celebration of the Eucharist, and so rendered the Jewish wine-seller a party to idolatry; others permissively turned a blind eye as Christian servants made the challah for Jewish homes and thus adulterated the Sabbath meal. ${ }^{28}$ Perhaps most lenient of all was the assertion that male converts to Christianity remained "Jews." ${ }^{29}$

The contrast of rabbinic treatment of female apostates is stark. Rashi, for instance, promoted the idea that women seized in pogroms and forcibly converted were probably raped and, so defiled, need not be accepted as a wife by their husbands should they return to Judaism and to the Jewish community. ${ }^{30}$ The thirteenth-century Rabbi Yitzhak ben Moshe went a step further by presuming that women who had been comparably captured would use any means at their disposal to save their lives-not only succumbing to rape (as opposed to suicide) but also by using their bodies to seduce and ingratiate themselves to their tormentors. ${ }^{31}$ And, the eleventh-century Rabbi 
Hai b. Sherira Gaon pronounced that even a woman who had apostatized but who later repented and returned to the community was not a "Jew" in the same way her male counterpart was, but, "like a harlot." ${ }^{2}$ As Rachel Furst has shown, these rabbis perpetually implicated forcibly converted or apostate women because the conquest of their bodies damaged the Jewish body politic. Their status was significant not only because Jewish women had been violated or demeaned but also because such violation emasculated the community's male population through defilement of their women and affirmed the diasporic subservience of the entire group." 33

The association of illicit sex, irreligion of some sort, and a disastrous outcome for the Jewish community is hardly confined to, or representative of a medieval Ashkenazic context any more than Toledot were only intended to convey an anti-Christian parody of Jesus' conception, life, and death. Rather, the trope was reinvigorated generation after generation as a response to initially diminished and then diasporic living conditions that Jews of a retributory bent blamed themselves for and symbolized through defiled femininity. Their view was probably informed by contemporary events-like the above noted conversion crisis of the high through late Middle Ages-but it was also owing to a typological understanding of history and literature that had been ingrained into Jewish tradition for millennia. ${ }^{34}$ Within this conception, events, motifs, and personae foreshadow and prefigure reoccurring events in Israel's on going history. Bearing this designation in mind, when a collection of stories tell of a Jewish woman who conceived a child with a man other than her husband who would torment and divide the community, readers and listeners would have likely associated the Toledot's message with a group of texts relating a similar scenario pertaining to Israel's history.

Each of the three segments of the Hebrew Bible include the same exclusionary message. The historical books of Numbers and Leviticus, for example, mentioned above in connection to the punishment for idolatry and blasphemy, indicate that illicit sexual union influenced Israel to sin against God. The writings are sometimes less straight forward. Nevertheless, the poetry of the Song of Songs has long been interpreted as a plea to God that he not forsake Israel and leave his people to engage in unspecified, but presumably illicit unions that would incite divine retribution and communal devastation. ${ }^{35}$ Yet, within the biblical text, the prophets provide the closest correlation to Toledot in terms of their collaborative presentation of a sustained metaphor of illicit union and their didactic function. For example, the book of Isaiah figuratively relates the decline of the Northern Kingdom to the Assyrians, the fall of Jerusalem, and the deportation of 


\section{6 | NATALIE E. LATTERI}

much of the population to Babylon using the by-now familiar motif. In it, the author referred to the city of Jerusalem, symbolic of Israel's political autonomy and God's election, as a "whore" (Isa 1:21), full of "offspring who do evil" and "children who deal corruptly" (Isa 1:4). In due course, he clarified that the initial insult of Jewish whoredom was a warranted description of those who had forsaken proper devotion to God in favor of material gains.

Like Isaiah, the book of Jeremiah describes the decline of Jewish political autonomy as a byproduct of the growth of the Babylonian Empire. And, in similar fashion, the author took up the metaphor of Israel as a whoring Jewess when, addressing Israel as God, he proclaimed: "On every high hill and under every green tree you sprawled and played the whore" (Jer 1:20) and "You have played the whore with many lovers" (Jer 3:1). Read typologically, the whore(s) of Isaiah and Jeremiah bears some similarities to the Miriam(s) of the Toledot-not to mention, the Talmudic-tradition. Each "woman" was unfaithful to one she had pledged fidelity to-a husband/ betrothed and God, respectively—and both produced offspring who tormented the community.

The Book of Hosea, composed during the eighth century B.C.E. and the Book of Ezekiel, written during the Babylonian Exile, also employ symbolic whoredom. In Hosea, the metaphor is sustained throughout as the author recounted the promiscuity of the unfaithful wife (the Northern Kingdom in this instance) who God would see return to Him but who He makes no qualms about serving just desserts to. In Ezekiel, by contrast, the metaphor is intermittently employed. The "whore" in question is, once again, Jerusalem on the verge of destruction, desecrated because of Jewish spiritual infidelity (see Ezek 23). But the lasciviousness projected onto those who would assimilate or even find any part of Gentile culture appealing is more descriptive than in the other prophetic texts, and the punishment more volatile and evocative of coerced coupling and widespread, long-term destruction. Of God's erstwhile Bride, the prophet wrote: "She did not give up her whorings that she had practiced since Egypt ... Therefore I delivered her into the hands of her lovers, into the hands of the Assyrians, for whom she lusted. These uncovered her nakedness; they seized her sons and her daughters; and they killed her with the sword. Judgment was executed upon her, and she became a byword among women" (Ezek 23:8-10).

In each of these biblical examples, the whoredom of a personified and feminized Israel referred to some form of spiritual infidelity Jews had committed that provoked God's wrath and resulted in the separation and destruction of the community. The words were those of the zealous mi- 
nority who did not distinguish the lax observance of Jews who engaged in questionable economic activity with Gentiles from those who engaged in idolatry, or between those who were forced to assimilate and those who did so willingly. All were whores. The message is fundamentally the same as that found in Toledot accounts of the extramarital conception of Jesus if read figuratively: that is, Jews had been and would continue to be punished for over-familiar relations with Gentiles (or impious Jews) they had, historically, had a difficult time resisting. Thus, the function: a didactic warning against falling into the same pitfall as the lusty or victimized Miriam qua Israel who had, time and again, perceptually played the whore in an evershrinking realm of Jewish autonomy.

\section{ACKNOWLEDGMENTS}

An earlier version of this paper was delivered at the 26th annual Midwest Jewish Studies Association conference held at Kent State University, September 2014. I would like to extend my gratitude to the association's officers and fellow conference participants for their warm reception and encouragement and to the University of New Mexico's Graduate and Professional Student Association for the generous Student Research Grant which helped to fund my conference participation.

\section{EDITOR's NOTE}

Shofar is pleased to join with the Midwest Jewish Studies Association in encouraging graduate work in Jewish Studies by publishing each year the paper chosen at the annual Midwest Jewish Studies Conference to receive the Graduate Student Paper Award. Natalie E. Latteri was the 2014 recipient.

\section{NOTES}

1. Scholars continue to speculate and debate when and where the Toledot Yeshu emerged as a written text in some recognizable form to what we have now. However, they are in agreement that oral stories of a similar vein to that found in the Toledot Yeshu circulated in addition to, if not prior to, the extant textual recensions. For an indication of some of the many scholarly contentions regarding the date of Toledot Yeshu compositions, see Peter Schäfer, introduction to Toledot Yeshu ("The Life Story of Jesus") Revisited, ed. Peter Schäfer, Michael Meerson, and Yaacov Deutsch (Tübingen: Mohr Siebeck, 2011), 3-11.

2. There also exist Latin and vernacular translations of Toledot Yeshu but, to my knowledge, these do not amount to different versions of the "Stories about Jesus."

3. Yaacov Deutsch, "New Evidence of Early Versions of Toldot Yeshu," (in Hebrew) Tarbiz 69 (2000): 184-86. 


\section{8 | NATALIE E. LATTERI}

4. Eli Yassif, "Toledot Yeshu: Folk-Narrative as Polemics and Self Criticism," in Toledot Yeshu Revisited, 119-21.

5. This segment of Toledot became a standard detail within Latin Christian translations, and so, may have been among those more widely diffused in medieval Christendom. See Ruth Karras, "The Aerial Battle in the Toledot Yeshu and Sodomy in the Late Middle Ages," Medieval Encounters 19 (2013): 507-08.

6. For a succinct discussion of biblical and antique Jewish tendencies to categorize non-Jewish religion as magic or idolatry, see Michael D. Bailey, Magic and Superstition in Europe: A Concise History from Antiquity to the Present (New York: Rowman and Littlefield, 2007), 38-42, particularly Egypt due to Moses's confrontation with Pharaoh's priests, 40. For an indication of western European ideas of Egypt as a font of magical knowledge during the late Middle Ages and Renaissance periods, see Frances Yates, Giordano Bruno and the Hermetic Tradition (Chicago: University of Chicago, 1964), 1-19.

7. Further references to idolatry and blasphemy are numerous within the biblical text. Here, perhaps it is enough to note the Ten Commandments' prohibition against these two shortcomings (see Exod 20:3, 7). Idolatry specifically will be discussed further below.

8. Samuel Krauss, "Une nouvelle recension hébraïque du Toldot Yeshu," Revue des études juives 103 (1938): 66-68, noted the significance of context in the details of Toledot as early as 1938. Following suit, Morris Goldstein emphasized the significance of context in the transmission of Toledot Yeshu more than sixty years ago when he wrote, "No two editions of Toledoth Yeshu are identical in all points; therefore, in addition to what is common to all, each minor variation conveys a message-as to the external conditions at the time of writing (or copying), as to details in the story heard or read of Jesus and Christianity or as to the thought process, the culture and knowledge of the author and the means whereby he thought he could render a service to his oppressed co-religionists." Morris Goldstein, Jesus in the Jewish Tradition (New York: Macmillan, 1950), 165. See also Adina M. Yoffie, "Observations on the Huldreich Manuscripts of the Toledot Yeshu," in Toledot Yeshu Revisited, 68; Michael Meerson, "Meaningful Nonsense: A Study of Details in Toledot Yeshu,"in Toledot Yeshu Revisited, 181-95. For an indication that Christians also chose Toledot recensions to translate based on the inclusion of details that could be employed as justification for contextually relevant persecution, see Karras, "Aerial Battle in the Toledot Yeshu," 498-99.

9. Amos Funkenstein, "Anti-Jewish Propaganda: Pagan, Medieval and Modern,” Jewish Quarterly 19 (1981): 59, presents the Toledot as Jewish polemic akin to antique Christian and Pagan peoples' critique of Judaism via inversion of sacred writings. David Biale, "Counter-History and Jewish Polemics against Christianity: The Sefer Toldot Yeshu and the Sefer Zerubavel," Jewish Social Studies 6, no. 1 (1999): 137, also presents the Toledot as an anti-Christian polemic; however, rather than an inversion of Christians' sacred text-the New Testament-he has categorized Toledot as a counter history. The majority position in current scholarship follows Biale's understanding. Only Eli Yassif in his above mentioned article, "Toledot Yeshu: Folk-Narrative as Polemics and Self Criticism" has analyzed at length an element of Jewish self-criticism in Toledot. The self-criticism he has observed, though, is that 
of non-elite Jews directed towards elite members of society, specifically in regards to youthful, student critiques of established rabbis.

10. I refer to the recension found in the Strasbourg manuscript. For an indication of the version's ubiquity, see William Horbury, "The Strasbourg Text of the Toledot," in Toledot Yeshu Revisited, ed. Peter Schäfer, Michael Meerson, and Yaacov Deutsch (Tübingen, Germany: Mohr Siebeck, 2011), 49-50, 53-54. What follows is my summary of the version of Toledot Yeshu found in the Strasbourg Manuscript: "The History of Jesus the Nazarene (According to the Hebrew Codex Strasburg)," trans. Hugh Schofield, in According to the Hebrews (London: Duckworth, 1937), 3561. For a partial list of manuscripts containing this common motif of Yosef ben Pandera as one who either tricked or raped Miriam and begat Yeshu, see Peter Schäfer, "Jesus' Origin, Birth, and Childhood according to the Toledot Yeshu and the Talmud," in Judaea-Palaestina, Babylon and Rome: Jews in Antiquity, ed. Benjamin Isaac and Yuval Shahar (Tübingen: Mohr Siebeck, 2012), 145n49.

11. See Deutsch, "New Evidence," 183.

12. See Yoffie, "Observations on the Huldreich Manuscripts," 67.

13. It is possible that differing details were merely a product of received tradition that ceased to be relevant to later generations of story tellers, but this seems unlikely given the expansion of specific scenarios-the conception of Jesus, his rape by Judas Iscariot, etc.-in the Toledot, which suggest an eagerness for each generation to shape stories of Jesus anew.

14. Peter Schäfer, Mirror of His Beauty: Feminine Images of God from the Bible to the Early Kabbalah (Princeton: Princeton University Press, 2002), 211-12; "Jesus' Origin, Birth, and Childhood," 160, provides a more prolonged discussion of his idea. Yoffie, "Observations on the Huldreich Manuscripts," 68, accepts Schäfer's position, seemingly without question.

15. No scholar, to my knowledge, has argued that Toledot were not Jewish stories for a Jewish audience. However, I believe that Schäfer's claim warrants a reiteration of a specifically Jewish milieu.

16. Amulo Lugdunensis, Liber Contra Judaeos, ch. 40, in Jacques-Paul Migne, ed., Patrologia Latina, vol. cxvi, col. 169D. Schäfer, "Jesus' Origin, Birth, and Childhood," 142, has translated Amulo's passage somewhat differently: Jesus was “impious and the son of an impious, namely, [someone] of uncertain origin, whom they call Pandera: with whom they say the mother of our Lord committed adultery ..." In the Latin, this sentence reads: "confitentes eum esse impium et filium impii, id est, nescio cujus ethnici, quem nominant Pandera: a quo dicunt matrem Domini adulteratam, et inde eum in quem nos credimus, natum." Schäfer's translation of ethnici does not relate the quality of pagan/heathen that the term probably conveyed to Amulo. For, while Jerome's Vulgate presentation of ethnici (Matt 5:47) and ethnicus (Matt 18:17) were based on the Greek ethnikos, which is commonly translated into modern English as "Gentile," the Douay-Rheims edition, which is closer to the Vulgate text known to Amulo than either the Greek or modern Bibles, translates ethnici and ethnicus as heathens/heathen. In addition, "pagan" or "heathen" as an understanding of ethnicus was an authoritative translation of the term, established by Church Father Tertullian (160-220 C.E.) in his De pudicitia, 


\section{0 | NATALIE E. LATTERI}

IX. 7: See Charlton T. Lewis and Charles Short, "Ethnicus," in A Latin Dictionary (Oxford: Clarendon Press, 1879). Many thanks to Timothy Graham for suggesting the above reference. Schäfer's translation of adulteram is also problematic in that it presents Miriam as an active party to adultery rather than the passive recipient of defilement, which the verb form suggests was the case in Amulo's account.

17. Schäfer, "Jesus' Origin, Birth, and Childhood," 142.

18. Karras, "The Aerial Battle in the Toledot Yeshu," 501.

19. Luke 1:28; Luke 1:30; Luke 1:38. Mary's status as "ever-virgin" has a history dating to early Christianity and this dogma remains part of the Catholic Catechism (I. 2. ii).

20. The thirteenth-century Dominican theologian, Thomas Aquinas, established the definitive position of the Catholic Church on the subject of free will in his Summa Theologiae (I. 23.iii): the only choice humans had was the ability to elect to be part of God's preordained planned or not. Mary and Christians after her were thus chosen and chose to be a part of God's salvation history, according to the Thomist position.

21. See Schäfer, Jesus in the Talmud, 15-24.

22. The second chapter of Luke relates the story of Jesus at the Temple. Rather than returning home with his family from their yearly visit to Jerusalem, he was found sitting among the teachers of the Law. When asked by his mother how he could cause Joseph and herself to worry such, he responded with a public statement affirming that Joseph was not his father: "Why were you searching for me? Did you not know that I must be in my Father's house?" (Luke 2:49)

23. The closest thing to a trial connected with Mary's extramarital conception in the New Testament is when Matthew 1:19 addresses the lack of legislation against Mary by indicating that Joseph wanted to avoid a public shaming of her: "Joseph, being a righteous man and unwilling to expose her to public disgrace, planned to dismiss her quietly."

24. See Jacob Katz, Exclusiveness and Tolerance: Studies in Jewish-Christian Relations in Medieval and Modern Times (London: Oxford University Press, 1961), 70-71; Simha Goldin, "Juifs et juifs convertis au Moyen Age: 'Es-tu encore mon frère?" Annales. Histoire, Sciences Sociales, 54e Année, no. 4 (1999): 853.

25. In biblical law, punishment for adultery was death by stoning. In contrast, a raped woman is absolved of guilt. The Talmud, in an extension of biblical legal discussion on the matter, includes stipulations whereby the woman who was raped was still forbidden to her husband in some circumstances and regarded as a harlot who was sequestered from the community: see BT Yevamot $56 \mathrm{~b}$.

26. Susan Einbinder, Beautiful Death: Jewish Poetry and Martyrdom in Medieval France (Princeton: Princeton University Press, 2002), 17-44, has examined this theme in liturgical poetry at length.

27. "The Chronicle of Solomon bar Simson," trans. Shlomo Eidelberg, in The Jews and the Crusaders: Hebrew Chronicles of the First and Second Crusades (Madison: University of Wisconsin Press, 1977), 54. See also "The Chronicle of Solomon bar Simson," trans. Robert Chazan, in European Jewry and the First Crusade (Berkeley: University of California Press, 1987), 279; "The Chronicle of Solomon bar Samson," 
trans. Jeremy Cohen, in Sanctifying the Name of God: Jewish Martyrs and Jewish Memories of the First Crusade (Philadelphia: University of Pennsylvania Press, 2004), 143.

28. Katz, Exclusiveness and Tolerance, 27-8, 38-40.

29. Ibid., 69-71.

30. See Rashi on Ketubbot 26b, s.v. “Asurah le-ba' alah”; Avodah Zarah 23a, s.v. "Tedah.”

31. Rachel Furst, "Captivity, Conversion, and Communal Identity: Sexual Angst and Religious Crisis in Frankfurt, 1241," Jewish History 22, no. 1/2. The Elka Klein Memorial Volume (2008): 192.

32. Ozar Ha-Geonim, Ketubbot, no. 789 in B. M. Levin, ed., Ozar Ha-Geonim, vol. 8 (Jerusalem: Mosad HaRav Kook, 1939), 356.

33. Furst, "Captivity, Conversion, and Communal Identity," 199.

34. The question of the existence of a historical consciousness among premodern Jews has often been raised, and many scholars have opined that medieval and antique Jewish sources are deficient in this regard. (For excellent treatment of this topic in full, see Michael Brenner, Prophets of the Past: Interpreters of Jewish History, trans. Steven Rendall (Princeton: Princeton University Press, 2010). The consensus, however, appears to be predicated on a linear model that favors modern Western historiography as the standard. Premodern non-Jewish writings widely recognized as historical, such as the Venerable Bede's Ecclesiastical History of the English People, are, like medieval Jewish historical sources, heavily informed by biblical typology.

35. See Rashi on Shir Ha-Shirim, 1:7.

\section{BIBLIOGRAPHY}

Amulo Lugdunensis. Liber contra judaeos. Volume CXVI of Patrologiae Cursus Completus, Series Latina. Edited by Jacques-Paul Migne. Paris: Ateliers Catholiques, 1844-1855.

Aquinas, Thomas. Summa Theologiae. Edited by Laurence Shapcote, John Mortensen, and Enrique Alarcón. Lander, WY: Aquinas Institute for the Study of Sacred Doctrine, 2012.

Babylonian Talmud. Edited by Isidore Epstein. New York: Bloch, 1990.

Bailey, Michael D. Magic and Superstition in Europe: A Concise History from Antiquity to the Present. New York: Rowman and Littlefield, 2007.

Biale, David. "Counter-History and Jewish Polemics against Christianity: The Sefer Toldot Yeshu and the Sefer Zerubavel." Jewish Social Studies 6, no. 1 (1999): 130-45.

Blidstein, Gerald I. "The Personal Status of Apostate and Ransomed Women in Medieval Jewish Law." Annual of the Institute for Research in Jewish Law 3-4 (1976-77): 35-116.

Brenner, Michael. Prophets of the Past: Interpreters of Jewish History. Translated by Steven Rendall. Princeton: Princeton University Press, 2010.

Chazan, Robert. European Jewry and the First Crusade. Berkeley: University of California Press, 1987. 


\section{2 | NATALIE E. LATTERI}

Cohen, Jeremy. Sanctifying the Name of God:Jewish Martyrs and Jewish Memories of the First Crusade. Philadelphia: University of Pennsylvania Press, 2004.

Deutsch, Yaacov. "New Evidence of Early Versions of Toldot Yeshu." Tarbiz 69 (2000): 177-97.

Eidelberg, Shlomo, ed. The Jews and the Crusaders: Hebrew Chronicles of the First and Second Crusades. Madison: University of Wisconsin Press, 1977.

Einbinder, Susan. Beautiful Death: Jewish Poetry and Martyrdom in Medieval France. Princeton: Princeton University Press, 2002.

Funkenstein, Amos. "Anti-Jewish Propaganda: Pagan, Medieval, and Modern.” Jewish Quarterly 19 (1981): 56-72.

Furst, Rachel. "Captivity, Conversion, and Communal Identity: Sexual Angst and Religious Crisis in Frankfurt, 1241.” Jewish History 22, no. 1/2, The Elka Klein Memorial Volume (2008): 179-221.

Goldin, Simha. "Juifs et juifs convertis au Moyen Age: 'Es-tu encore mon frère?'” Annales. Histoire, Sciences Sociales, 54e Année, no. 4 (1999): 851-74.

Goldstein, Morris. Jesus in the Jewish Tradition. New York: Macmillan, 1950.

Karras, Ruth. "The Aerial Battle in the Toledot Yeshu and Sodomy in the Late Middle Ages." Medieval Encounters 19 (2013): 493-533.

Katz, Jacob. Exclusiveness and Tolerance: Studies in Jewish-Christian Relations in Medieval and Modern Times. London: Oxford University Press, 1961.

Krauss, Samuel. "Une nouvelle recension hébraïque du Toldot Yeshu." Revue des études juives 103 (1938): 65-88.

Ozar Ha-Geonim. Volume 8. Edited by B. M. Levin. Jerusalem: Mosad HaRav Kook, 1939.

Schäfer, Peter. "Jesus' Origin, Birth, and Childhood according to the Toledot Yeshu and the Talmud," 139-64. Judaea-Palaestina, Babylon and Rome: Jews in Antiquity. Edited by Benjamin Isaac and Yuval Shahar. Tübingen: Mohr Siebeck, 2012.

Schäfer, Peter, Michael Meerson, and Yaacov Deutsch, eds. Toledot Yeshu ("The Life Story of Jesus") Revisited. Tübingen: Mohr Siebeck, 2011.

Schäfer, Peter. Mirror of His Beauty: Feminine Images of God from the Bible to the Early Kabbalah. Princeton: Princeton University Press, 2002.

Schofield, Hugh. According to the Hebrews. London: Duckworth, 1937.

Yates, Frances. Giordano Bruno and the Hermetic Tradition. Chicago: University of Chicago, 1964. 